\title{
Para-Nasal Sinuses Bone Bank について
}

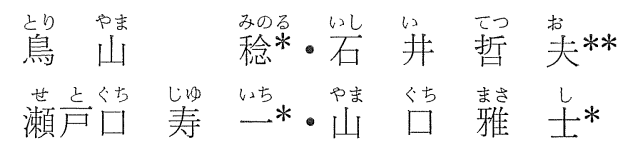

1.はじめに

現在耳の研究, 手術の修練には, 病玵解㳯の際, 米国の Schuknecht らが開発し, ストライカー 社の特製の円筒鋸をもちいて, 傊頭骨の中に, 内耳道・内耳・中耳・外耳道の一部を含めて, 切除 し，乙の摘出標本を利用し，Temporal bone bank と呼び，多くの成果をあげてきた。すすおち

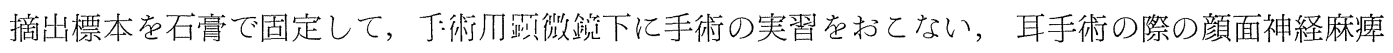
などの合併症の発生を著しく減少させ, さらにてれをもちいて顔面神経減圧手術, 鐙骨手術, 鼓室 形成手術などの実習も容易となってきた。 また一方ての標本の生前の聴力と連続切片の病理所見と を比較し，難聴の将过沺し)解叮:こいちじるしい効果をあげてきた。

しかし鼻, 副鼻腔についてのこうした Temporal bone bank system 式のものは, 現在まで諸

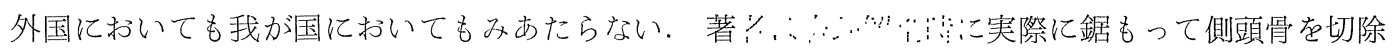
する際に Para-nasal sinuses bone bank そついて思いついた。

元来鼻, 副鼻腔の解剖の実習については，古くは Zuckerkandl ${ }^{1)}$, Denker Kahler ${ }^{2)}$ の本があり Davis ${ }^{3)}$ ら本とともに鼻, 副鼻腔の病场解乵则の摘出法なども簡単に書かれている。またわが国に おいても，足川氏5 ${ }^{5}$ の論文に鼻，副鼻腔の標本の摘出方法が，わずかであるが記載されている，し かしてれが Temporal bone bankのように発達しなかったのは，ての部分の摘出に際して被解剖 体の顔面を傷つけたり，笮骨洞がこわれたりして標本を摘出するてとが困難であったてとが原因で なかったかと思われた，著者らは Para-nasal sinuses bone bank についての考え方と，その採取 方法についてのべ, さらにその臨床面, 研究面での利用についてのべ, 諸氏の御批判を仰ざたい.

\section{2. 標本の摘出のための条件}

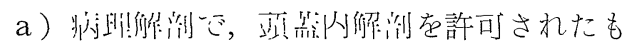
の. 頭蓋を開頭するための切断には, 特別な配 慮の必要はない.しかし前頭部切断はできるだ け低い位置の方が円筒鋸の方向を自由にとれ る. 前頭部が高いと円筒鋸の方向が前方に向い すぎて眼窩内角を傷つけるととがある。このた

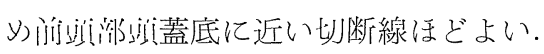

b ）ストライカー社製の電動鋸があること. その先は，永島社製またはストライカー社製の 円筒鋸が必要である。ストライカー社製の電動
鋸は，病理解剖をおてなう施設ではどてにでも ある. 円筒鋸の底の部分（モーター側）には 3 つの穴があいている，その面に円形のボール紙 を入れておくのもよい方法である（理由は後 述). 永島，ストライカー社製の円筒鋸は電動 機に固定する部分は三角になり，直径 $3.8 \mathrm{~cm}$ の円筒形で筒部の高さは $5 \mathrm{~cm}$ であり，その先

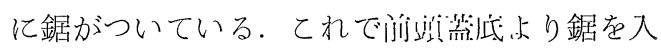
れると鼻腔底までの距離より短かい。乙れよ り $2 \mathrm{~cm}$ 長い円筒鋸をもちいれば，上顎骨より

Para-Nasal Sinuses Bone Bank.

Minoru Toriyama, Tetsuo Ishii, Juichi Setoguchi and Masashi Yamaguchi.

*関東学災病院耳鼻呐唤科

水帝京大学医学部开鼻呕喉科学教空 
口腔天蓋までを防て 標本の 摘出に 都合がよ い.

その他，鋏，メス，手術用コッヘル氏止血錙
子さらに簡単な骨鈿子などで，特別なものは不 用である.

\section{3 標本摘出の実際}

a）円筒鋸を入れる。開頭し下垂体を摘出し たあと前頭窩の鶏冠を含み正中部で，節状板よ り，後方は視神経管の頭蓋内入口よでを含めて 円筒鋸をのせる。乙の場合穊状板，嗅裂など前 方を研究・実習するつもりであれば，前方に， 視神経管，蝶形洞を目的とすれば後方に，上顎 洞，眼简内や下鼻甲介までも一部とりたいとき には，正中部よりやや右側とか左側に，位置さ せる。すなわち目的により位置を決める。一般 そ正中部よりおとしても而側下鼻甲介までの標 本は入る。

b ）円筒鋸の刺入する方向. まず左手の人差

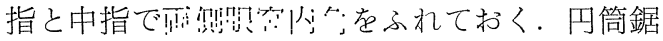
を前方にむけたとき，乙の部分が最も傷つけら れやすいからで，初期（はじぬの $2 \sim 3$ 回）は むしろ方向を後方に向けて入れるようにすべき

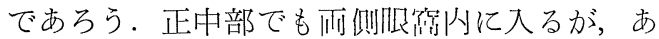
まり側方に向ければ左右いずれかの眼简内に広 く入る，後方に向けるととは最も安全である が，後部は頸椎第 1 , 第 2 骨，翼口蓋突起など にまで達すると摘訬に，後方の結合がつよく 摘出しにくい，側方に向けても眼球を傷つける ことはほとんどない（今まで約40例のうちての 部の損傷は 1 例もなかった). 上咽頭腫演のと きは梯形台から後方頸椎までを妨く。

c）円筒鋸にスイッチを入れる。できれば左

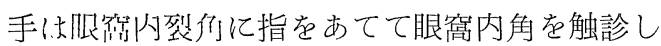
ながら頭蓋を固定する。円筒鋸を右手にもって 頭蓋底を抜けば下は穊骨蜂巢であり，急激に下 方に進入する。 円筒鋸が一杯に入ったならば， 円筒鋸は作動させたまま抜いてくる。このとき
円筒鋸が允分に長ければ硬口蓋をぬけ口腔内に 入り，この円筒の中に標本が入っている．この 際円筒鋸を回転などさせると，時には，穊骨蜂 巣，鼻中隔とも下方で自動的に切断されて，円 筒鋸の中に標本が入ったまま抜けてくるてとも ある。乙れらの場合には，標本摘出条件のb) 項にも述べたようにボール紙を入れてあれば, 円筒鋸の底の丸い穴よりコッヘル氏鋁子などで 押せば，標本をいためずにそのまま押し出し摘 出することができる。

d）䀫鋸が入った所が図 1 で ある. こののち鼻内より球頭解剖剪刀（メイヨ の鋏でもよい）をもちいて，尖頭部で鼻中隔を 右より左に貫通させて，下鼻甲介切除のでとく 後方に一杯に鼻中隔を軟骨部, 鋤骨, と切断す る、鋏またはノミを用いてさらに両側の下鼻道 の外側を切断して上顎洞に入り（対孔の部分） これを後方に充分切断する.てうして鼻内より 鼻中隔矯正用鈿子などで標本を上にもちあげる か，鶏冠を骨鉗子などではさんで上方にひきあ げれば標本を摘出できる．また後方をとるため に蝶形骨洞から上咽頭に好ている場合には， 咽頭後壁に水平にノミを入れれば後方部分の標 本を摘出できる。同じ操作を頭蓋内よりおてな う場合には，トルコ鞍の後床突起をノミでおと して蝶形骨洞に入り，その下方上り上咽頭に如 ける。こてょり解剖鋏を用いて後方より前方に 鼻中隔を切断すれば標本をうるととができる。

これらの操作は 3 分から 5 分位のうちにおわ るととができる。でく初歩の人でも10分とはか からない簡単な方法である。

\section{4. 摘出後の処置}

鼻，副鼻腔を上記の方法で摘出した場合頭蓋 内と鼻，咽頭と洔には口腔と直結した一つの腔
となる。また眼窩内の脂肪の一部, 眼简内・上 部の骨欠損を生じて收域队阶をおてす。しかし 

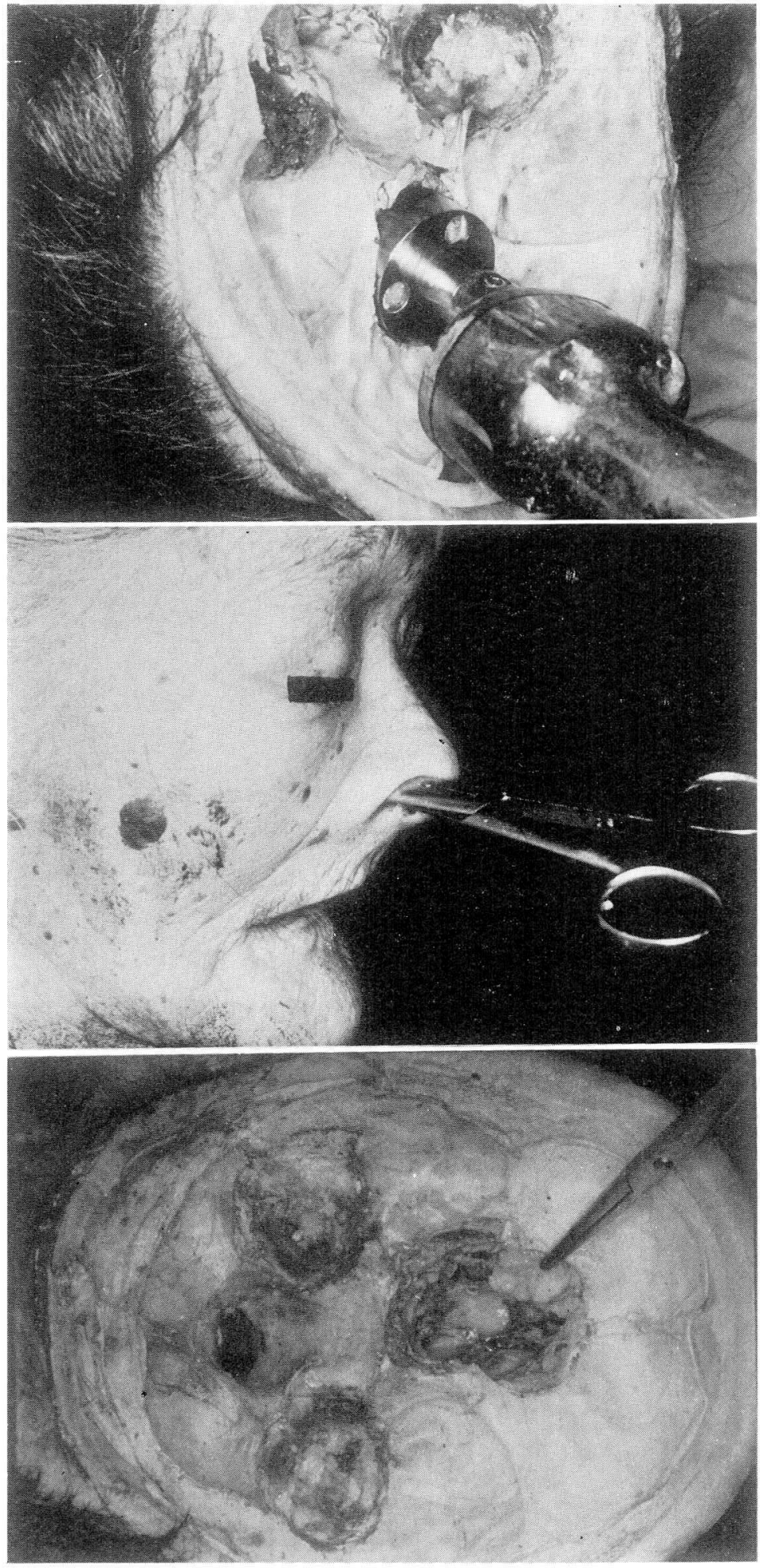

図 1 同筒鈮と鋏に上る標本切断法と, 摘出後の頭蓋底(側頭骨も摘出してある) コッヘル氏鎮子の先は視神経断端をしめす 

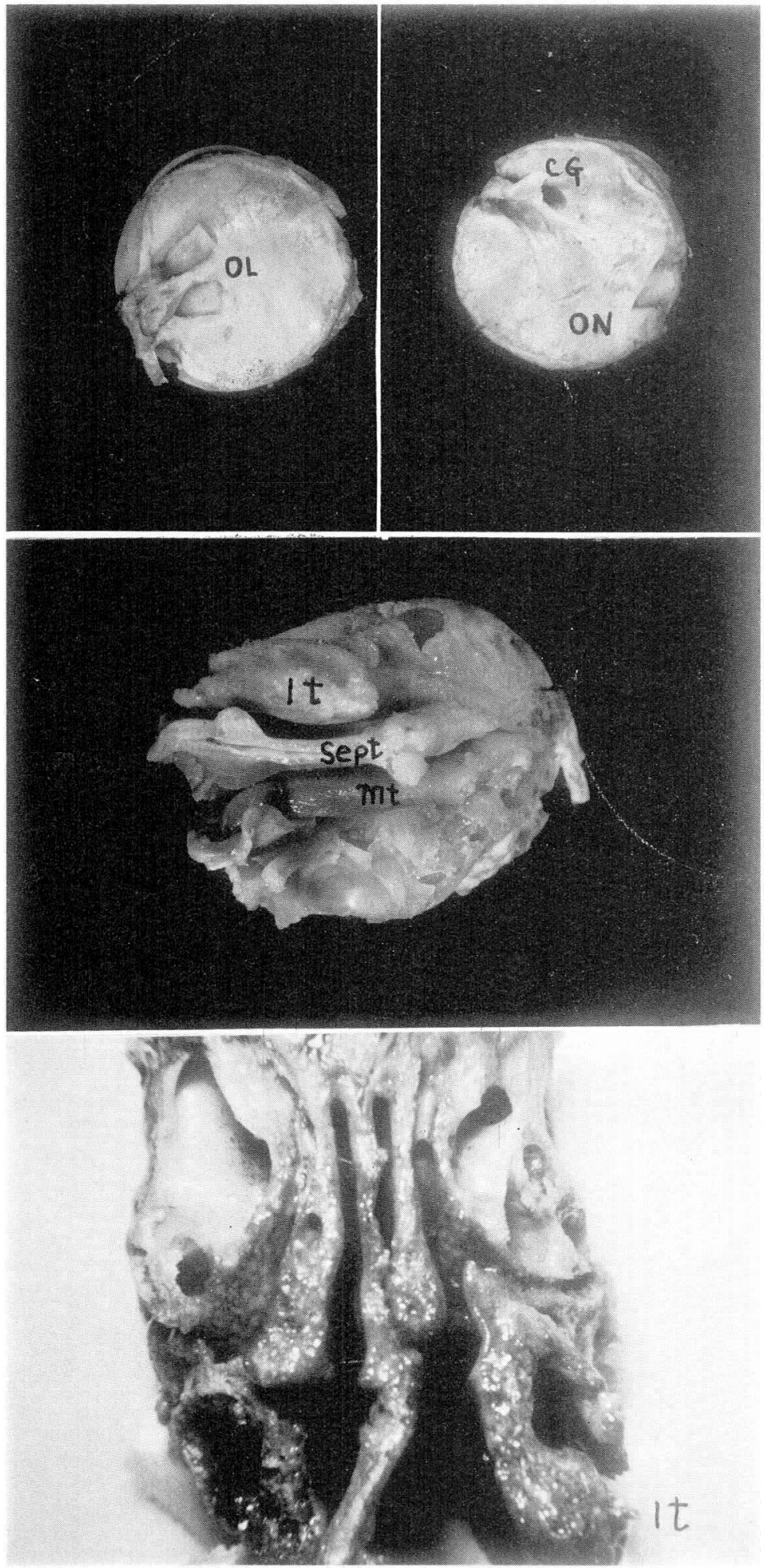

$\mathrm{OL}$ : 嗅神経 CG : 鵴冠 $\mathrm{ON}$ : 視神経 It : 下鼻甲介 $\mathrm{mt}$ : 中鼻甲介 Sept : 鼻中隔 図 2 摘出慓本の上, 下, 正面図 
この際鞍鼻をおこすとか，外鼻には全然変形は 拈きない，鼻内より大きな綿栓を雨側に入れて 鼻腔を閉鎖する。つづいて頭蓋内より綿または ガーゼを人れて眼窩内を光渾し，眼球をもとの 位置にもどす。との際綿は入れすぎるより少な

\section{5 , 摘 出 標 本}

摘手標本は上面よりみると表面全体は硬䯕膜 に被われていて, 前頭蓋底の中に鷄冠, 嗅系と きには嗅球も含んでいる。

後方は蝶形骨の前中央部の中に視神経を, 外 側は眼窩天蓋，前頭洞天蓋に相当する.

前方よりみると外側部には両側前頭洞の一 部，眼窝天蓋，穊骨洞（前部），鼻中隔，中鼻 甲介, 中鼻道, 下鼻甲介, 下鼻道, 上顎洞内側
目の方がよい、口腔内からも綿を入れておく。

こうしてあとは病理解剖法にしたがって頭蓋内 に綿・ガーゼを入れて頭皮を縫合する。

以上の操作は約 $4 \sim 5$ 分でおわる.
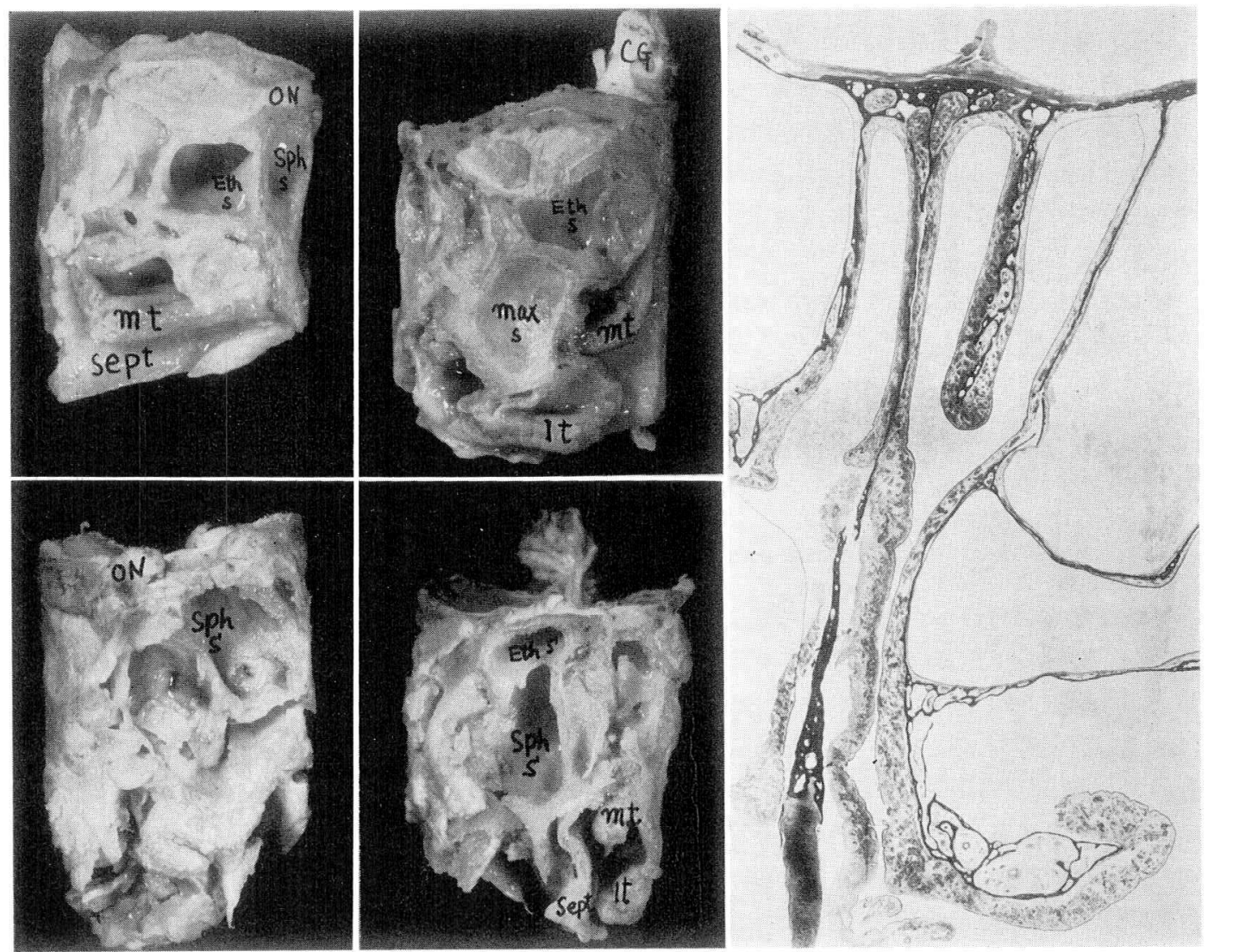

壁などを含む。鼻涙管は時としては一部入るこ ともあるが，含まれるととはまれである。

下方よりみると下鼻甲介, 下鼻道, 鼻中隔, 上顎洞の内側壁, 中鼻甲介を含んでいる。鼻中 隔後端は鉫骨を含んでいる.

側方よりみると前頭洞，眼窝内側の脂肪，後 方は視神経，動眼神経，テノン氏膜，前・後部 穊骨洞，蝶形骨洞，中鼻甲介，上䕱洞内側壁，

図 3 摘出標本の側面，後面と運続切片の一部，Sphs：蝶形骨洞，Eths：節骨洞，ｍaxs：上䫜洞 とくに後面図では蝶形骨洞の自然孔，蝶形骨洞上の箱骨洞もみられる， 
膜様部，上顎洞自然孔を含んでいる.

後方よりみると視神経管, 蝶形骨洞, その出 口，鼻中隔，下鼻甲介を含んでいる.

内部は前頭洞, 篩骨洞, 上顎洞, 蝶形骨洞と 上中下の 3 鼻甲介と，鉤状突起など，また翼口 蓋孔，Vidian 神経などが含まれている。

すなわち一部づつではあるがての標本は，す
べての副鼻腔, 嗅糸, 視神経など鼻, 副鼻腔手 術，研究に大切なものをすべて含んでいる.

欠点としては鼻涙管，涙囊などを含まず，ま た上顎洞自然孔か膜様部近くで弱く，とてが切 れることがある。この点については，円筒鋸の 直径をあと $1 \mathrm{~cm}$ 位大きくする必要がある。

\section{6. 摘出標本の利用}

a) 解剖学上：標本をホルマリンで固定し, 脱灰，セロイシン迎後に連続大切片をつくり 立体感, 解剖学の実習, 学習に利用する。この 場合矢状面切断, 前額面切断, 水平面切断の三

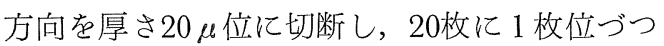
を染壬する. 嗅, 呼吸粘膜の分布・嗅糸系, 視 神経などの神経分布，血管分布などについての 立体的感覚をうえつける. とくに臨床的に大切 なものは修淔而切断の連続切片である。

b ）鼻・副鼻腔の病理組織学上の研究：この 連続切片をもちいて，鼻・副鼻腔し将四䊶䄉”。 的な変化を研究するととができる。著者ら ${ }^{6)}$ これをもちいて，ヒト搝粘膜上皮の年令变化に ついてすでに報告した，今後さらに副鼻腔炎手 術後, 悪性腫陽の浸潤などについても報告する 予定である.

c）手術実習：摘手標本のみでも手術などの 訓練に有効である。すなわち鋭匙，鋭匙鈿子な
ぞで，手術の訓練をおてないながら解剖学を学 習できる。乙れは主として鼻内用の訓練に適し ているので, 人間の外鼻, 頭盖底, 眼䈝などを ふくめてての切除標本をのぞいた，模型をつく っておく．「佖汌約の際には摘出標本を頭蓋底 より挿入し, 頭蓋底に摘出標本を固定する。乙 れで手術訓練を抢てなえば，副鼻腔鼻内手術の 技術が向上する. 使用後に標本をとり出し新し い標本を入れ換えれば，模型は 1 つでも何回で も汀洲し、練存おてなうととができる。こうし た実習を少なくとも5 回以上の標本について実 習し，解剖上の個体差などを学習した上で，鼻 内手術の実際をおてなうべきであろう。てうし た訓練をまた，ときどきくりかえすととによ り，近件线判们題にまで発展する鼻・副鼻腔手 術の際における髄膜炎, 視力障㫪などの事故を 防ぐよう努力すべきであろう。

\section{Para-nasal sinuses bone bank の機構}

病理解剖をおてなうことのできる施設はすく ないが，300床以上の病院では必らず毎年何例

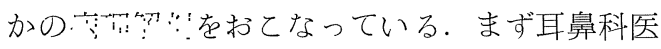
は他科の・・立ちあって，自ら鼻・副鼻 腔標本を摘出してみるべきであろう，つづいて 病理の技術者に鼻・副鼻腔の標本切除法をおし える、耳鼻科医であれば道具さえあれば $5 \sim 10$ 分の時間でとれるので，自分でとった方がよ い. 標本をホルマリンにつけて，大学病院・地 域病院に保存する。これがすなわち Para-nasal sinuses bone bank である. 必要に応じててて そ申し込めば， Para-nasal sinuses bone の標

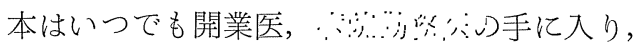
前記の模型をつけて貸し出せば，訓練するとと ができる。鼻内よりの下垂体，視神経開放術な どの訓練にも有効な方法である，とくに特殊手 術の前にはこのBank 標本をもちいて訓練して から手術にかかるべきであろう。またててには 連続切片標本をおいて，いつでも顕微鏡下でも 学習できる状態にすべきであろう。 


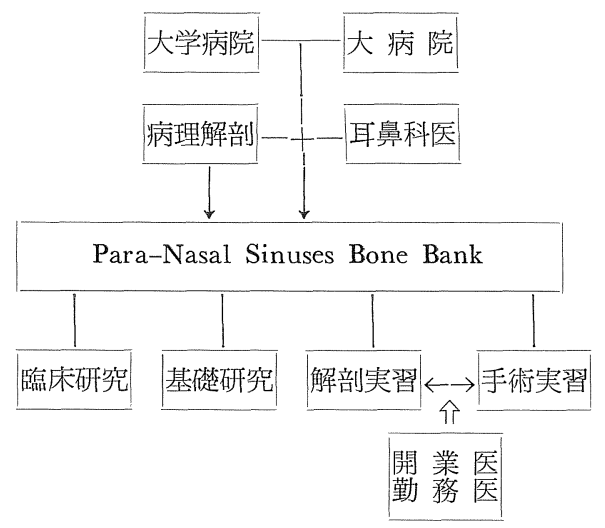

図 4 Para-Nasal Sinuses Bone Bank System について, 医療機関との関係

\section{8.まと め}

この論文は鼻・副鼻腔の解剖の実習書でも解説書でもない，鼻・副鼻腔の標本実習によって，耳 鼻科医の鼻・副鼻腔の知識と実技を向上させ，さらに鼻・副鼻腔の研究に役立つ手段をのべたにす ぎない。その際には萩野 ${ }^{8)}$, 寉田 ${ }^{7)}$, Denker Kahler ${ }^{2}$, Alyea ${ }^{4}$ らの本を参照として実習されれば よい.

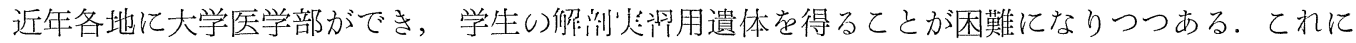

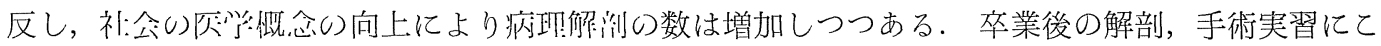
の摘出標本を利用し，体の棈造上最も複雑な鼻・副鼻腔についての知識を向上させ，手術による視

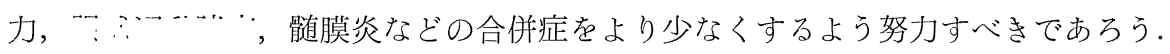

しかし遺体より標本を摘手することは，とりもなおさず遺体を傷つけるととであり，こてに哲学 的な問題がでてくる，標本をもちいて実習する人は常にての点に留意して遺体の一部として，慎し んで標本を提供した患者さんに感謝して実習を抗てなうべきであろう.

また，乙うした遺体の一部を摘出することについては，法医学的，法的な問題ものてるであろ う。しかしてれらは，より多くの患者の不幸を予防するために許されるであろう.

本諭文は，耳鼻咽喉科臨床に扔ける問題点と解決への試み，第 2 回鼻の場合。49年 4 月14日日本耳鼻咽喉科 学会関東地方会, 教育パネル・シリーズにおいて発表した.

また本文を書くにあたり御援助いただいた㮌天堂大学病理学橋本敬裕教授，関東労災病院検查部長関口英輔 先生，宮城孝治検查技師，および帝京大学法医学石山昱夫教授に感謝いたします。またパネルの場において，種 々お教えいただいた干葉大学北村武教授, 慈恵大学高橋良教授, 足川力雄助教授に感謝いたします。

\section{文}

1) Zuckerkandl, E. : Normale und Pathologische Anatomie der Nasenhöhle und ihrer pneumatischen Anhänge. Wilhelm Braumüller, Wien, 1893.

2) Denker, A. und Kahler, O. : Handbuch der Hals-Nasen-Ohren Heilkunde. Julius Springer, Berlin, 1928.

\section{献}

3) Davis, W.B. : Development and anatomy of tenasal accessory sinuses in man. W.B. Saunders, Philadelphia, 1914.

4) Van Alyea. : Nasal sinuses. Williama and Wil1kins, Baltimore, 1942.

5）足川力雄 : 穊骨. ‘ ・ $・$ とそ の臨床, 耳展 1:159-195, 1957. 
6）石井哲夫，鳥山稔：ヒト嗅粘膜上皮の加令による 組織学的変化, 耳鼻臨床 $66: 7 ; 779-789,1973$.

7）窪田一胤：副鼻腔の臨床解剖网説, 日耳鼻 72 : 3 号增刊, 1969.

8) 荻野朝一：! '
1967.

原稿 到着：昭和49年 5 月 13 日 別刷請求先：鳥山 稔 荳211 川崎市中原区木月住吉町2035

関東労災病院耳鼻咽喉科 